\title{
EFEITO FOUCAULT NA ANÁLISE ORGANIZACIONAL
}

\author{
Por Alexandre Reis Rosa \\ Mestrando em Administração pelo PPGA-UFLA \\ E-mail: alexandrereisrosa@hotmail.com
}

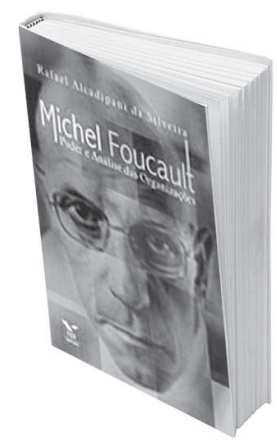

MICHEL FOUCAULT: PODER E ANÁLISE DAS ORGANIZAÇÕES

De Rafael Alcadipani da Silveira

Rio de Janeiro: Editora FGV, 2005. 167 p.

Os maiores pensadores são aqueles que não apenas "fazem descobertas" importantes, como afirmou Émile Durkheim, pois essa é a tarefa de qualquer cientista, mas também são aqueles que causam à sua volta uma mudança no modo de pensar, indagar e escrever. Michel Foucault pertence a esta última categoria, ao alterar a maneira como os estudiosos das mais diversas áreas do conhecimento concebem e exercem seus ofícios. Um exemplo disso foi o "importante deslocamento de gestalt" sofrido pelo teórico organizacional Gibson Burrell ao ler a obra Vigiar e punir no final dos anos 1980. Até então, os estudos organizacionais em contexto anglo-saxão não haviam tido contato com o pensamento desconcertante deste intelectual que modificou o cenário acadêmico na segunda metade do século XX.

Sua analítica se constituiu numa ruptura com a concepção clássica de poder. A mudança de "posse" para "processo" caracterizou uma abordagem dinâmica e não estática do conceito de poder, gerando um impacto profundo nas discussões sobre o tema nos anos que se seguiram. Em meio à efervescência da filosofia francesa do pós-guerra, Foucault tratou de ocupar um lugar de destaque nas discussões contemporâneas e nos estudos organizacionais. Em particular, é um dos autores mais citados nas publicações ligadas ao movimento dos critical management studies (CMS).

$\mathrm{Na}$ trilha desse movimento, Rafael Alcadipani nos brinda com um importante ensaio sobre a contribuição do pensamento foucaultiano à área organizacional. Embora o esforço já tenha sido realizado no contexto internacional por meio de artigos, esse é sem dúvida o primeiro no contexto brasileiro. Fruto de sua dissertação de mestrado, o livro apresenta uma análise aprofundada das principais idéias do autor e um exame criterioso da produção científica publicada nos principais periódicos de circulação mundial.

O capítulo inicial do livro procura situar o leitor não apenas em relação a essas publicações, mas principalmente em relação aos antecedentes que marcaram a entrada do pensamento foucaultiano na análise organizacional. Da abertura paradigmática que gerou alternativas à visão funcionalista, passando pelas discussões no âmbito da labor process theory (LPT) até o recente movimento dos CMS, o capítulo mostra uma predominância de trabalhos em torno do poder disciplinar que é apenas uma, entre outras, das contribuições da analítica de poder proposta por Foucault. 
Na seqüência, os três outros capítulos da obra apresentam o conjunto de abordagens que marca a referida analítica. Como observa Alcadipani, deve-se entender que a obra de Foucault distribui-se em três etapas arqueologia, genealogia e ética -, e que entre elas não há rupturas bruscas, mas deslocamentos de ênfases metodológicas em que cada uma buscou se alinhar a eixos específicos de análise. Cabe destaque à genealogia, que teve como foco o eixo do poder que se distribui também em três etapas: o poder disciplinar, a biopolítica e a governamentalidade. Outro ponto destacado é que não há uma teoria geral do poder em Foucault, pois suas análises consideram o poder em seu funcionamento local, em campos específicos e em áreas determinadas. Assim, Foucault subverte o establishment ao enfocar o poder como algo que se constrói, que possui um caráter relacional, e que não é de propriedade de quem domina, em detrimento ao dominado. Mas sim como algo que circula e atravessa todos os indivíduos dispostos numa dada relação. Ou seja, ele é capilar e está presente em todas as instâncias da sociedade, desde a família, passando pela fábrica até o Estado nacional.

Como se vê na análise das publicações apresentada no capítulo inicial, o enfoque dos estudos organizacionais tem sido direcionado à genealogia do poder e suas tecnologias sobre o corpo, que é tido como epicentro de sua análise. Tal perspectiva vai desde o poder disciplinar - que fornece a noção de microcorpo, que recebe um treinamento "ortopédico" com o objetivo de se tornar submisso, dócil e útil, passando pela biopolítica - que discute o corpo-molar, entendido como pertencente a uma espécie (população), com suas leis e regularidades, até as formulações em torno da governamentalidade, vista como a maneira de dirigir a conduta dos indivíduos e dos grupos, governando os homens e as coisas.

Não obstante as diferenças entre os três pontos da genealogia, a norma se apresenta como o ponto comum de articulação entre eles, pois pode ser aplicada tanto em um corpo a ser disciplinado como em um grupo a ser regulado. Como argumenta Foucault, se onde há poder há resistência, a gestão das coisas e das pessoas representada pela governamentalidade pode se deparar com uma "atitude crítica" que subentende uma recusa de ser governado segundo determinadas normas. Em linhas gerais, os capítulos procuram demonstrar que existem outras possibilidades de análise que vão além das disciplinas, e que utilizar recortes teóricos dessa analítica sem a devida contextualização acaba levando a uma instrumentalização simplificada dos conceitos, como se fosse uma "caixa de ferramentas conceitual".

Com vistas a denunciar essa prática, no quinto e último capítulo do livro o autor se propõe a problematizar a análise organizacional foucaultiana em três frentes: primeiro, destaca que direcionar o foco somente no poder disciplinar e nos seus mecanismos é negligenciar parte importante das idéias do pensador; segundo, que enquadrá-lo dentro de uma epistemologia pós-moderna é simplificar seu legado e ir contra aspectos importantes de sua obra; e terceiro, incluir outros autores no debate sem avaliar se há compatibilidade de idéias é na verdade construir uma grande "colcha de retalhos" conceitual. Feitas essas observações, a segunda parte do capítulo final é dedicada a possíveis desenvolvimentos para a análise organizacional a partir da analítica de poder foucaultiana.

Apesar de questionar os usos e abusos do pensamento foucaultiano e ainda indicar possíveis desenvolvimen- tos no campo organizacional, o livro deixa de abordar possíveis aplicações no contexto brasileiro. A vinculação com os critical management studies produz um tom eurocentrista para a discussão e desloca o leitor para um espaço social diferente do nosso. Ou seja, ao deixar de apontar os desdobramentos que poderiam ser utilizados para uma análise crítica das organizações brasileiras, apresenta uma análise descontextualizada e desvinculada da nossa especificidade sócioorganizacional.

Não obstante, considerando em seu sentido geral e amplo a organização, cuja compreensão da dinâmica interna e externa depende de uma perspectiva multidisciplinar de análise, o trabalho de Alcadipani constitui uma contribuição significativa. $\mathrm{Na}$ medida em que expõe o conteúdo teórico do campo ao crivo crítico, revela uma série de processos subliminares relacionados ao controle, à vigilância, à construção da subjetividade e às desigualdades de gênero, outrora ignorados pela abordagem tradicional dos estudos organizacionais.

Dessa forma, a discussão apresentada no livro revigora a corrente crítica no âmbito dos estudos organizacionais brasileiros inaugurada por Alberto Guerreiro Ramos, Maurício Tragtenberg, Fernando Prestes Motta e, mais recentemente, por José Henrique de Faria. Neste momento em que a academia da área de Administração experimenta uma fase de amadurecimento e de crescente internacionalização, a obra se apresenta como uma oportunidade de refazer uma leitura dos nossos erros e acertos. As entrelinhas do texto sinalizam para o leitor que o rumo dos estudos organizacionais no país deve contemplar uma clara noção dos limites e das possibilidades existentes, delineando a fronteira entre a reflexão desejável e a reflexão possível. 